\title{
Prediction of SWCC of Saline Soil in Western Jilin Based on Arya-Paris Model
}

\author{
BAO Shuochao ${ }^{1,2}$ a, WANG Qing ${ }^{1, b}$ and WANG Zijian ${ }^{3, c}$ \\ ${ }^{1}$ College of Construction Engineering, Jilin University, Changchun, China \\ ${ }^{2}$ College of Civil Engineering, Jilin Jianzhu University, Changchun, China \\ ${ }^{3}$ Jilin Team of Geological Survey Center of China Building Materials Industry, Changchun, \\ China \\ abaoshuochao@126.com¹, bwangqing@jlu.edu.cn, ${ }^{\text {c3} 355899156 @ q q . c o m ~}$
}

\begin{abstract}
The saline soil distributed in Western Jilin Province could cause a serious of damages to local construction engineering and agriculture. The relationship between water content and soil suction has great influence on engineering properties, and effect the water migration and forming of saline soil. This paper aims to the saline soil in Zhenlai area of Western Jilin province, the basic properties test were taken in laboratory, and Arya-Paris prediction model were chosen to predict the SWCC of saline soil in Western Jilin. The results show that the $30 \mathrm{~cm}$ soil sample has lower water holding capacity than the $50 \mathrm{~cm}$ soil sample, which means the water migration rate is higher of $30 \mathrm{~cm}$. The results may provide theoretical support and beneficial reference for research and prediction of engineering properties and forming mechanism of saline soil.
\end{abstract}

\section{Introduction}

Saline soil is a kind of special soil which soluble salt content in the soil is more than $0.3 \%$, and has special engineering properties such asdissolve, salt expansion and corrosion.Soil salinization will not only make the function of agricultural cultivated land, grassland degradation and to the overall environment deteriorating, but also can cause corrosionof building foundation, road salt expansion, frost heaving, pumping fall, transmission line and a series of engineering disaster. Therefore, the study of water, salt and heat migration law is very important of saline soil. As an unsaturated soil, the soil- water characteristic curve of soil is significance.

Soil-water characteristic curve shows the relation between water content and matrix suction, it reflects the suction role soils water-holding capacity.For access to the soil water characteristic curve, it only can be measured according to the experiment or model for fitting way currently, including pressure gauge, tension meter, sand funnel method, centrifuge

* Corresponding author: baoshuochao@126.com 
method, etc.But whatever the test method, all test cycle is long, the high test cost and the data is discrete.

Model fitting methods include empirical formula method, the fractal model of soil water characteristic curve method, soil transfer function method, physical experience model method, etc.Ayra, Paris and Zhuang proposed a method to predict soil water characteristic curve according to the soil particle size distribution, heavy, grain density and other parameters. This method can the use of limited known data farthest, and the degree of curve fitting is very high, also is applicable to the cohesive soil.

Based on the analysis of contrast methods for various types of soil water characteristic curve fitting model, according to the characteristics of the saline soil in westernJilin, Arya Paris prediction model is selected to predict the soil water characteristic curve of saline soil in westernJilin province, the prediction results can be used to analysis the water properties and engineering properties of saline soil in westernJilin, and provide the basis of water and salt migration mechanism and salinization processof saline soil in westernJilin province.

\section{Introduction of Arya-Paris Model}

Arya and Paris found that the SWCC is very similar to soil particle cumulative distribution curve on shape. Based this regulation, they propose a model to calculate SWCC according to the particle distribution and dry density. The model includes two parts:

\subsection{Pore Volume and Volume Moisture Content}

According to the soil particle size distribution curve, particle size distribution can be divided into the $i$ intervals, each interval of soil pore volume is set to $\mathrm{V}_{\mathrm{vi}}$, which can be calculated by formula (1):

$$
\mathrm{V}_{\mathrm{v}_{\mathrm{i}}}=\left(W_{i} / \rho_{s}\right) e_{i=1,2, \ldots, \mathrm{n}}
$$

In formula (1),Wi is the unit soil quality of No. $i$ interval, $\rho \mathrm{s}$ is sol particles density, $e$ is pore ratio, which can be calculated as:

$$
e=\left(\rho_{d} / \rho_{s}\right)-1
$$

Assuming water filled small pores firstly and then filled large pores during water filling progress. So the volume water content can be calculated as:

$$
\theta_{\mathrm{v}_{\mathrm{i}}}=\sum_{j=1}^{\mathrm{j}=i} V_{v_{j}} / V_{b}
$$

$\mathrm{V}_{\mathrm{b}}$ is unit volume of soil, which can be calculated as:

$$
\mathrm{V}_{\mathrm{b}}=\sum_{\mathrm{i}=1}^{\mathrm{i}=\mathrm{n}} \mathrm{W}_{\mathrm{i}} / \rho_{\mathrm{d}}=1 / \rho_{\mathrm{d}}{ }_{i=1,2, \ldots, \mathrm{n}}
$$

So,

$$
\theta_{\mathrm{v}_{\mathrm{i}}}=\sum_{j=1}^{\mathrm{j}=i} V_{v_{j}} \cdot \rho_{\mathrm{d}}
$$


Final volume water content of soil pore is averaged by adjacent intervals volume water content:

$$
\theta_{\mathrm{v}_{\mathrm{i}}}^{*}=\left(\theta_{\mathrm{v}_{\mathrm{i}}}+\theta_{\mathrm{v}_{\mathrm{i}+1}}\right) / 2
$$

\subsection{Soil Particle Size and Pore Radius}

Arya-Pari model is based on three assumption:

(1) Soil particles are spherical, all soil particles radius are equivalent to size of ball radius $R_{i} ;$

(2) The pores in soil are all cylinder capillary, the radius ri is related to soil particle radius $R_{i}$;

(3) Soil particles at each intervals are composed by ni soil particles, the capillary pore total length of hi. The i interval soil particle volume and soil pore volume are obtained by formula (7) and (8):

$$
\begin{aligned}
& V_{p_{i}}=n_{i} 4 \pi R_{i}^{3} / 3=W_{i} / \rho_{s} \\
& V_{v_{i}}=\pi r_{i}^{2} h_{i}=\left(W_{i} / \rho_{s}\right) e
\end{aligned}
$$

Vpi is the total soil particle volume of i interval, Vvi is the total soil pore volume of $i$ interval. Take formula (8) divided by formula (7):

$$
\mathrm{r}_{i}^{2} / R_{i}^{3}=4 n_{i} e / 3 h_{i}
$$

According to the assumption that for $\mathrm{h}$, the total length of tube pore, think the value is approximate along the pore channels in multiples of soil particle size distribution, then, for the idealistic composed of spherical particles in the I interval should be equal to the total length of the porosity of the soil $n_{i} 2 R_{\mathrm{i}}$. But because in the real soil, pore length effected by the soil particle shape, size and arrangement, and the actual soil particles are not globule, cause another hypothesis is each of the actual soil particle formation pore length is greater than the equivalent grain, then introduces the experience of a greater than 1 parameter makes the $n_{i} \alpha>n_{i}$ to modify the $h_{i}, h_{i}=n_{i} \alpha 2 R_{i}$, pore radius can be expressed as:

$$
\mathrm{r}_{\mathrm{i}}=R_{i}\left[4 e n_{i}^{(1-\alpha)} / 6\right]^{1 / 2}=0.816 R_{i} \sqrt{e n_{i}^{(1-\alpha)}}
$$

Take the result of formula (7) into formula (10), the number of soil particles of $i$ interval is:

$$
\mathrm{n}_{i}=3 W_{i} /\left(4 \pi \rho_{s} R_{i}^{3}\right)
$$

Basing the capillary action,matric suction water head of $i$ intercal is:

$$
\psi_{i}=2 \gamma \cos \theta / \rho_{w} g r_{i}
$$




\section{Prediction of SWCC of Saline Soil in Western Jilin}

\subsection{Soil Materials}

Soil samples taken from Zhenlai area, Jilin province, which taken from two depth at $30 \mathrm{~cm}$ and $50 \mathrm{~cm}$. Two samples were given as I-30 and II-50.

\begin{tabular}{|c|c|c|c|c|c|}
\hline \multicolumn{7}{|c|}{ Table 1 basic physical properties of soil samples } & \\
\hline $\begin{array}{c}\text { Sample } \\
\text { No. }\end{array}$ & $\begin{array}{c}\text { Natural water } \\
\text { content }(\%)\end{array}$ & $\begin{array}{c}\text { Density } \\
\rho\left(\mathrm{g} / \mathrm{cm}^{3}\right)\end{array}$ & $\begin{array}{c}\text { Dry } \\
\text { density } \rho_{\mathrm{d}}\left(\mathrm{g} / \mathrm{cm}^{3}\right)\end{array}$ & $\begin{array}{c}\text { Particle } \\
\text { density } \rho_{\mathrm{s}}\left(\mathrm{g} / \mathrm{cm}^{3}\right)\end{array}$ & Pore ratioe \\
\hline I-30 & 12.98 & 1.79 & 1.58 & 2.72 & 0.72 \\
\hline II-50 & 14.76 & 1.76 & 1.53 & 2.71 & 0.77 \\
\hline
\end{tabular}

Laboratory basic physical properties text and particle size distribution test were taken to two soil samples, the results are shown as Table 1 and Table 2.

\begin{tabular}{|c|c|c|c|c|c|c|c|}
\hline \multicolumn{7}{|c|}{ Table 2 soil particles distribution } \\
\hline \multirow{3}{*}{$\begin{array}{c}\text { Sample } \\
\text { No. }\end{array}$} & $\begin{array}{c}\text { Soil particles mass fraction }(\%) \text { at different particle size interval } \\
(\mu \mathrm{m})\end{array}$ \\
\cline { 2 - 8 } & 0 & 0 & 0 & 5 & & $5-2$ & $<2$ \\
\hline I-30 & 0 & 0.76 & 0.50 & 15.22 & 50.6 & 9.58 & 23.3 \\
& & & & & 1 & & 3 \\
\hline II-50 & 0 & 0.06 & 0.28 & 1.17 & 55.7 & 12.2 & 30.4 \\
& & & & & 9 & 7 & 3 \\
\hline
\end{tabular}

\begin{tabular}{|c|c|c|c|c|c|c|c|c|}
\hline \multicolumn{9}{|c|}{ Table 3 parameters calculation of arya- paris modle } \\
\hline $\begin{array}{c}\text { Samp } \\
\text { le } \\
\text { No. }\end{array}$ & $\begin{array}{l}\text { Particle size } \\
\quad(\mu \mathrm{m})\end{array}$ & $\mathrm{W}_{\mathrm{i}}(\mathrm{g})$ & $\begin{array}{c}\mathrm{V}_{\mathrm{vi}} \\
(\mathrm{cm} 3)\end{array}$ & $\theta_{\mathrm{vi}}$ & $\theta_{\mathrm{vi}}{ }^{*}$ & $\mathrm{n}_{\mathrm{i}}$ & $\mathrm{r}_{\mathrm{i}}(\mathrm{cm})$ & $\psi_{\mathrm{i}}(\mathrm{cm})$ \\
\hline \multirow{10}{*}{$\mathrm{I}-30$} & $1.21-4.2$ & 0.233 & 0.0666 & $\begin{array}{c}0.10 \\
2\end{array}$ & $\begin{array}{c}0.11 \\
6\end{array}$ & $\begin{array}{c}1.16 \times 10 \\
10 \\
\end{array}$ & $\begin{array}{c}1.06 \times 10 \\
-6\end{array}$ & $\begin{array}{c}1.39 \times 10 \\
5\end{array}$ \\
\hline & $4.2-5.8$ & 0.064 & 0.0183 & 0.13 & $\begin{array}{c}0.14 \\
4\end{array}$ & $\begin{array}{c}7.64 \times 10 \\
7\end{array}$ & $\begin{array}{c}9.58 \times 10 \\
-6\end{array}$ & $\begin{array}{c}1.55 \times 10 \\
4\end{array}$ \\
\hline & $5.8-8.4$ & 0.063 & 0.018 & $\begin{array}{c}0.15 \\
8 \\
\end{array}$ & $\begin{array}{c}0.16 \\
7 \\
\end{array}$ & $\begin{array}{c}2.85 \times 10 \\
7 \\
\end{array}$ & $\begin{array}{c}1.60 \times 10 \\
-5 \\
\end{array}$ & $\begin{array}{c}9.29 \times 10 \\
3 \\
\end{array}$ \\
\hline & $8.4-14.5$ & 0.041 & 0.0117 & $\begin{array}{c}0.17 \\
5\end{array}$ & $\begin{array}{c}0.18 \\
2\end{array}$ & $\begin{array}{c}6.11 \times 10 \\
6\end{array}$ & $\begin{array}{c}3.10 \times 10 \\
-5\end{array}$ & $\begin{array}{c}4.78 \times 10 \\
3\end{array}$ \\
\hline & $14.5-20.2$ & 0.028 & 0.0081 & $\begin{array}{c}0.18 \\
8\end{array}$ & $\begin{array}{c}0.19 \\
1\end{array}$ & $\begin{array}{c}8.22 \times 10 \\
5\end{array}$ & $\begin{array}{c}7.82 \times 10 \\
-5\end{array}$ & $\begin{array}{c}1.89 \times 10 \\
3\end{array}$ \\
\hline & $20.2-32.1$ & 0.012 & 0.0035 & $\begin{array}{c}0.19 \\
3\end{array}$ & $\begin{array}{c}0.19 \\
9\end{array}$ & $\begin{array}{c}1.30 \times 10 \\
5\end{array}$ & $\begin{array}{c}1.55 \times 10 \\
-4\end{array}$ & $\begin{array}{c}9.57 \times 10 \\
2 \\
\end{array}$ \\
\hline & $32.1-46$ & 0.026 & 0.0075 & $\begin{array}{c}0.20 \\
5\end{array}$ & 0.22 & $\begin{array}{c}7.02 \times 10 \\
4\end{array}$ & $\begin{array}{c}2.76 \times 10 \\
-4\end{array}$ & $\begin{array}{c}5.36 \times 10 \\
2 \\
\end{array}$ \\
\hline & $46-75$ & 0.068 & 0.0195 & $\begin{array}{c}0.23 \\
5\end{array}$ & 0.3 & $\begin{array}{c}6.20 \times 10 \\
4 \\
\end{array}$ & $\begin{array}{c}4.06 \times 10 \\
-4 \\
\end{array}$ & $\begin{array}{c}3.65 \times 10 \\
2 \\
\end{array}$ \\
\hline & $75-250$ & 0.298 & 0.0851 & $\begin{array}{c}0.36 \\
5\end{array}$ & $\begin{array}{c}0.39 \\
8 \\
\end{array}$ & $\begin{array}{c}6.23 \times 10 \\
4 \\
\end{array}$ & $\begin{array}{c}6.61 \times 10 \\
-4\end{array}$ & $\begin{array}{c}2.24 \times 10 \\
2 \\
\end{array}$ \\
\hline & $25-500$ & 0.152 & 0.0434 & $\begin{array}{c}0.43 \\
1\end{array}$ & $\begin{array}{c}0.43 \\
2\end{array}$ & $\begin{array}{c}8.58 \times 10 \\
2\end{array}$ & $\begin{array}{c}4.97 \times 10 \\
-3\end{array}$ & $\begin{array}{c}2.98 \times 10 \\
1\end{array}$ \\
\hline
\end{tabular}




\begin{tabular}{|c|c|c|c|c|c|c|c|c|}
\hline & $500-1000$ & 0.005 & 0.0014 & $\begin{array}{c}0.43 \\
3\end{array}$ & $\begin{array}{c}0.43 \\
5\end{array}$ & $\begin{array}{c}3.50 \times 10 \\
0\end{array}$ & $\begin{array}{c}2.83 \times 10 \\
-2\end{array}$ & $\begin{array}{c}5.24 \times 10 \\
0\end{array}$ \\
\hline \multirow{11}{*}{ II-50 } & $1.18-4.05$ & 0.304 & 0.0802 & $\begin{array}{c}0.12 \\
7\end{array}$ & $\begin{array}{c}0.15 \\
2\end{array}$ & $\begin{array}{c}1.63 \times 10 \\
10\end{array}$ & $\begin{array}{c}9.36 \times 10 \\
-7\end{array}$ & $\begin{array}{c}1.58 \mathrm{E} \times 1 \\
05\end{array}$ \\
\hline & $4.05-5.6$ & 0.123 & 0.0323 & $\begin{array}{c}0.17 \\
8 \\
\end{array}$ & $\begin{array}{c}0.18 \\
5 \\
\end{array}$ & $\begin{array}{c}1.62 \times 10 \\
8 \\
\end{array}$ & $\begin{array}{c}7.71 \times 10 \\
-6 \\
\end{array}$ & $\begin{array}{c}1.92 \mathrm{E} \times 1 \\
04\end{array}$ \\
\hline & $5.6-8.2$ & 0.036 & 0.0096 & $\begin{array}{c}0.19 \\
3\end{array}$ & $\begin{array}{c}0.20 \\
3\end{array}$ & $\begin{array}{c}1.82 \times 10 \\
7\end{array}$ & $\begin{array}{c}1.62 \times 10 \\
-5\end{array}$ & $\begin{array}{c}9.17 \times 10 \\
3\end{array}$ \\
\hline & $8.2-14$ & 0.047 & 0.0125 & $\begin{array}{c}0.21 \\
3\end{array}$ & $\begin{array}{c}0.22 \\
4\end{array}$ & $\begin{array}{c}7.55 \times 10 \\
6\end{array}$ & $\begin{array}{c}2.80 \times 10 \\
-5\end{array}$ & $\begin{array}{c}5.30 \times 10 \\
3\end{array}$ \\
\hline & $14-19.6$ & 0.053 & 0.0139 & $\begin{array}{c}0.23 \\
5\end{array}$ & 0.24 & $\begin{array}{c}1.69 \times 10 \\
6\end{array}$ & $\begin{array}{c}6.35 \times 10 \\
-5\end{array}$ & $\begin{array}{c}2.34 \times 10 \\
3\end{array}$ \\
\hline & $19.6-30.5$ & 0.027 & 0.0071 & $\begin{array}{c}0.24 \\
6\end{array}$ & $\begin{array}{c}0.26 \\
3\end{array}$ & $\begin{array}{c}3.13 \times 10 \\
5\end{array}$ & $\begin{array}{c}1.22 \times 10 \\
-4\end{array}$ & $\begin{array}{c}1.21 \times 10 \\
3\end{array}$ \\
\hline & $30.5-43$ & 0.084 & 0.0221 & $\begin{array}{c}0.28 \\
1\end{array}$ & $\begin{array}{c}0.29 \\
3\end{array}$ & $\begin{array}{c}2.59 \times 10 \\
5\end{array}$ & $\begin{array}{c}1.97 \times 10 \\
-4\end{array}$ & $\begin{array}{c}7.51 \times 10 \\
2\end{array}$ \\
\hline & $43-75$ & 0.058 & 0.0153 & $\begin{array}{c}0.30 \\
5\end{array}$ & $\begin{array}{c}0.35 \\
7\end{array}$ & $\begin{array}{c}6.40 \times 10 \\
4\end{array}$ & $\begin{array}{c}3.63 \times 10 \\
-4\end{array}$ & $\begin{array}{c}4.08 \times 10 \\
2\end{array}$ \\
\hline & $75-250$ & 0.253 & 0.0667 & 0.41 & $\begin{array}{c}0.41 \\
3\end{array}$ & $\begin{array}{c}5.27 \times 10 \\
4\end{array}$ & $\begin{array}{c}6.57 \times 10 \\
-4\end{array}$ & $\begin{array}{c}2.26 \times 10 \\
2\end{array}$ \\
\hline & $25-500$ & 0.012 & 0.0031 & $\begin{array}{c}0.41 \\
5\end{array}$ & $\begin{array}{c}0.41 \\
6\end{array}$ & $\begin{array}{c}6.56 \times 10 \\
1\end{array}$ & $\begin{array}{c}7.80 \times 10 \\
-3\end{array}$ & $\begin{array}{c}1.90 \times 10 \\
1\end{array}$ \\
\hline & $500-1000$ & 0.003 & 0.0007 & $\begin{array}{c}0.41 \\
6\end{array}$ & $\begin{array}{c}0.41 \\
6\end{array}$ & $\begin{array}{c}1.93 \times 10 \\
0\end{array}$ & $\begin{array}{c}3.05 \times 10 \\
-2\end{array}$ & $\begin{array}{c}4.86 \times 10 \\
0\end{array}$ \\
\hline
\end{tabular}

\subsection{Parameter Selection and Model Establishment}

According to the steps above, with the indoor test of the soil dry density of soil, soil particle density, pore ratio and particle size distribution of soil parameter, established Arya-Paris model of two soil samples from Zhenlai area, western Jilin. During calculation, take experience parameter $\alpha=1.38$, the water's surface $\gamma=72.6 \mathrm{mN} / \mathrm{m}$, contact angle $\theta=0^{\circ}$, the acceleration of gravity $\mathrm{g}=980 \mathrm{~cm} / \mathrm{s}^{2}$. Model calculation parameters as shown in Table 3 , the distribution of particle size is less than 75 microns is measured by water settling method, actual measurement to the particle size is not as an integer, so in order to guarantee the precision of the model, calculated with the measured soil particle size data.

\subsection{SWCC of Saline Soil in Western JILIN}

Arya-Paris Model were established of I-30 and II-50 sail samples from Zhenlai area, western Jilin. The SWCC are shown as Fig. 1.

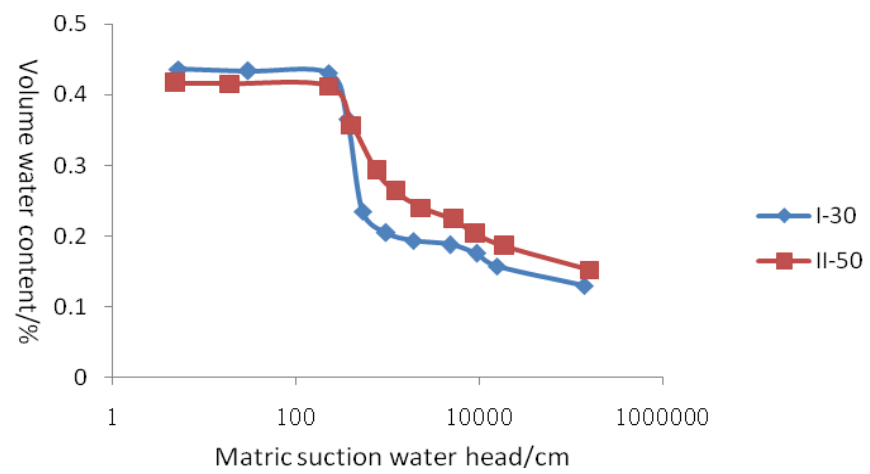

Fig.1 SWCC prediction result of soil samples 
As Fig.1 shown, there are two obvious inflection points in SWCC, which divid the curve into three parts. Those two inflection points are air suction and remnant water content, and three parts of SWCC are soild, liquid and gas condition of soil. Each part corresponding to different state of solid, liquid and gas.First period for the inlet section, basic performance curve for the level state, the matrix suction not intake value, moisture content is close to saturation, soil properties close to the saturated soil in this phase. The gases in the earth are suspended in the air bubbles in the water, moving in the water, the suction value is very small. Curve of the second paragraph curve slope increase, form an approximate diagonal lines. In this phase, the matrix suction gradually over intake value, the pore gas gradually connected, air into the ground, and larger channel between filling pore, the suction value began to increase. With the increase of the suction value constantly, the degree of saturation of soil fell rapidly, the properties of soil are in this range, great changes have taken place in general unsaturated soil are in the stage of the change. Into the curve of the third part, the soil water characteristic curve flattens out as the gases in the soil completely connected. Due to the stage in the soil moisture content has been smaller, matrix suction is higher, the moisture content in this phase change is very small.

$30 \mathrm{~cm}$ soil sample saturated moisture content is above $50 \mathrm{~cm}$ soil samples, but the soil sample is almost at the same time into unsaturated state in two places.In the second part of the curve of the transition zone, $30 \mathrm{~cm}$ soil slope is significantly higher than $50 \mathrm{~cm}$ soil samples, the curve is steep, shows that soil samples of dehydration rate faster, the water-holding capacity of soil is weak, the moisture migration rate faster.Moisture migration rate directly affects the area of the saline soil salinization process, this is because the soil moisture in the upward or downward migration, to dissolve in the water in the soil soluble salt substances such as migration accumulation. $30 \mathrm{~cm}$ soil samples the water-holding capacity of less than $50 \mathrm{~cm}$ soil sample, shows that the salt in shallow soil due to evaporation with moisture to near the surface of the aggregation rate faster, over time, the soil salinization degree increase.

\section{Conclusions}

1.Saline soil in west jilin belongs to the unsaturated soil, unsaturated soil theory of soil water characteristic curve could be used to predict the moisture migration characteristics.

2.Through the discussion of various kinds of soil water characteristic curve prediction method, determined using Arya - Paris model prediction in west jilin saline soil, the soil water characteristic curve from a point of view, this method can well predict the soil water characteristic curve of saline soil in west jilin.

3.According to the prediction of soil water characteristic curve, the town of adlai was in charge in shallow soil water-holding capacity significantly weaker than the deep soil, which can lead to moisture migration rate faster, in the shallow soil evaporation under the influence of salt aggravate the salinization rapidly accumulate near the body surface process.

4.In this paper, the saline soil in west jilin predictive results of the soil water characteristic curve was still in the stage of theory predicts, in the next step of work should be combined with experimental tests of soil water characteristics are measured.

\section{Acknowledgements}

This work was financially supported by Natural Science Foudation of China (41430642、41372267). 


\section{References}

1. Williams,P.J. :The surface of the Earth, an intro duction to geochemical science.New York: Longman Inc. (1982)

2. Fedlund, D.G \& Xing: Equations of the soil-water characteristic curve. Can. Geotech., (1994).

3. Zhao X.L.: The forecast model of soil water characteristic curve.Nanjing:Hehai University(2007) (In Chinese).

4. Arya, L. M. \& Paris, J.F. :A physicoempirical model to predict the soil moisture characteristic from particle-size distribution and bulk density data. Soil Science Society of America Journal, (1981).

5. Zhuang J., Yan J., Miyazaki, T.: Estimating water retention characteristic from soil particle-size distribution using a non-similar media concept. Science( 2001).

6. Bao S.C.,Wang Q.,Wang W.H.:Influence of freezing-thawing process on dispersibility of cohesive soil in western Jilin seasonal frozen region. Journal of Engineering of Heilongjiang University(2014) (In Chinese)..

7. Wang Q.A.:Based on the localized parameters to predict soil water characteristic curve. Beijing: Beijing Jiaotong University(2009) (In Chinese).

8. Childs, E. C. \& Collis-George,N.: The permeability of porous materials. Proceedings of the Poyal Society of London( 1948).

9. Vanapalli, S. K., Fredlund, D.G. \& Pufahl, D. E.:The influence of soil structure and stress history on the soil-water characteristics of a compacted till. Geotechnique(1999). 